OPEN ACCESS

Edited by:

Carlos Rosales,

Universidad Nacional Autónoma de

México, Mexico

Reviewed by:

Bruno Vogt

University of Bern, Switzerland

Timothy J. Moss,

Ritchie Centre, Australia

${ }^{*}$ Correspondence:

Sandra Rodrigues-Mascarenhas sandra@cbiotec.ufpb.br

Specialty section:

This article was submitted to Integrative Physiology, a section of the journal

Frontiers in Physiology

Received: 06 September 2017 Accepted: 24 October 2017 Published: 10 November 2017

Citation:

Cavalcante-Silva LHA, Lima ÉA,

Carvalho DCM, Sales-Neto JM,

Alves AKA, Galvão JGFM, Silva JSF and Rodrigues-Mascarenhas S (2017)

Much More than a Cardiotonic

Steroid: Modulation of Inflammation

by Ouabain. Front. Physiol. 8:895.

doi: 10.3389/fphys.2017.00895

\title{
Much More than a Cardiotonic Steroid: Modulation of Inflammation by Ouabain
}

\author{
Luiz H. A. Cavalcante-Silva ${ }^{1}$, Éssia de Almeida Lima ${ }^{2}$, Deyse C. M. Carvalho ${ }^{3}$, \\ José M. de Sales-Neto ${ }^{1}$, Anne K. de Abreu Alves ${ }^{2}$, José G. F. M. Galvão', \\ Juliane S. de França da Silva ${ }^{1}$ and Sandra Rodrigues-Mascarenhas ${ }^{1,2,3 *}$
}

${ }^{1}$ Programa de Pós-Graduação em Produtos Naturais e Sintéticos Bioativos, Laboratório de Imunobiotecnologia, Centro de Ciências da Saúde, Universidade Federal da Paraíba, João Pessoa, Brazil, ${ }^{2}$ Programa de Pós-Graduação em Biotecnologia, Laboratório de Imunobiotecnologia, Centro de Biotecnologia, Universidade Federal da Paraíba, João Pessoa, Brazil, ${ }^{3}$ Programa Multicêntrico de Pós-graduação em Ciências Fisiológicas, Laboratório de Imunobiotecnologia, Centro de Biotecnologia, Universidade Federal da Paraíba, João Pessoa, Brazil

Since the discovery of ouabain as a cardiotonic steroid hormone present in higher mammals, research about it has progressed rapidly and several of its physiological and pharmacological effects have been described. Ouabain can behave as a stress hormone and adrenal cortex is its main source. Direct effects of ouabain are originated due to the binding to its receptor, the $\mathrm{Na}^{+} / \mathrm{K}^{+}$-ATPase, on target cells. This interaction can promote $\mathrm{Na}^{+}$transport blockade or even activation of signaling transduction pathways (e.g., EGFR/Src-Ras-ERK pathway activation), independent of ion transport. Besides the well-known effect of ouabain on the cardiovascular system and blood pressure control, compelling evidence indicates that ouabain regulates a number of immune functions. Inflammation is a tightly coordinated immunological function that is also affected by ouabain. Indeed, this hormone can modulate many inflammatory events such as cell migration, vascular permeability, and cytokine production. Moreover, ouabain also interferes on neuroinflammation. However, it is not clear how ouabain controls these events. In this brief review, we summarize the updates of ouabain effect on several aspects of peripheral and central inflammation, bringing new insights into ouabain functions on the immune system.

Keywords: ouabain, immune system, peripheral inflammation, cell migration, cytokines, neuroinflammation

\section{INTRODUCTION}

Although the cardiotonic steroid ouabain was originally identified as a plant secondary metabolite (e.g., from Strophantus gratus and Acokanthera ouabaio), it was later described as an endogenous mammalian substance (Hamlyn et al., 1991) such as other cardiotonic steroids (e.g., marinobufagenin and digoxin) (Bagrov et al., 2009). Ouabain was found in bovine adrenal gland (Laredo et al., 1994; Schneider et al., 1998), adrenal gland tumors (Blanco and Wallace, 2013), bovine hypothalamus (Tymiak et al., 1993), bovine hypophysis (Schoner, 2002), and human plasma (Hamlyn et al., 1991; Ferrandi et al., 1997). It is noteworthy that ouabain isolated from mammalian tissues and body fluids is structurally, biochemically, and immunologically indistinguishable to ouabain isolated from plants (Schoner, 2002). 
Ouabain synthesis seems to occur in the zona glomerulosa and fasciculata of the adrenal gland cortex (Masugi et al., 1988; Laredo et al., 1995), using hydroxycholesterol, pregnenolone, and progesterone (Hamlyn et al., 1998; Schoner and ScheinerBobis, 2007) as precursors. Thereafter, ouabain is released into the circulation after stimulation by adrenocorticotropic hormone (Lewis et al., 2014), epinephrine (Schoner and Scheiner-Bobis, 2005), angiotensin II (Laredo et al., 1997), and $\alpha 1$-adrenergic receptor agonists (Schoner, 2002; Schoner and Scheiner-Bobis, 2007). In rats, the physiological role of ouabain is associated to vasculature tone control and natriuresis (Nesher et al., 2009).

Ouabain levels are increased in different conditions such as chronic renal insufficiency (Stella et al., 2008), chronic salt intake (Blanco and Wallace, 2013), congestive heart failure (Manunta et al., 2009, 2010), hypertension (Hauck and Frishman, 2012), pregnancy (Dvela-Levitt et al., 2015), and primary hyperaldosteronism (Rossi et al., 1995). This steroid is also associated with stress conditions, such as physical exercise (Antolovic et al., 2000; Bauer et al., 2005). In addition, high levels of ouabain are correlated with cortisol concentration (Berendes et al., 2003), which reinforces its role as a stress hormone.

Besides its role as a $\mathrm{Na}^{+} / \mathrm{K}^{+}$-ATPase (sodium pump) inhibitor (Lingrel, 2010), which is associated with cardiovascular effects (Hamlyn and Blaustein, 2013; Blaustein et al., 2016), ouabain, at low concentrations, triggers $\mathrm{Na}^{+} / \mathrm{K}^{+}$-ATPasemediated signaling pathways (Xie and Askari, 2002; Xie and Cai, 2003). These relayed signals cascades include Src kinase, MAPK, and NF- $\mathrm{B}$ activation, reactive oxygen species release and others (Saunders and Scheiner-Bobis, 2004; Aperia, 2007). Ouabain induces several biological regulatory effects, including cell proliferation, hypertrophy, apoptosis (Bagrov et al., 2009) resulting in different functional outcomes. Additionally, it has been demonstrated that ouabain modulates various immune system functions (Rodrigues-Mascarenhas et al., 2009), including inflammation. In this mini-review, we present the relationship between ouabain and inflammatory process.

\section{OUABAIN AND IMMUNE SYSTEM}

The immune system is a highly specialized network of lymphoid organs, cells, humoral factors, and cytokines, which acts in order to maintain homeostasis (Parkin and Cohen, 2001). The relationship between ouabain and immune system was first studied when Quastel and Kaplan (1968) demonstrated that this steroid inhibits lymphocytes proliferation induced by the mitogen phytohaemagglutinin. This effect was later confirmed by several other reports that used different stimuli (e.g., anti-CD3 and IL-2) (Jensen et al., 1977; Dornand et al., 1986; Redondo et al., 1986; Olej et al., 1994; Brodie et al., 1995; Szamel et al., 1995). This phenomenon could be related to CD25 (Pires et al., 1997) and IL-2 reduced expression (Dornand et al., 1986; Szamel et al., 1995) induced by ouabain, since both molecules are required for lymphocyte proliferation. Moreover, ouabain reduces regulatory $\mathrm{T}$ cells absolute number in mice (Silva et al., 2015). It is noteworthy that CD25 is highly expressed and fundamental to regulatory T cells survival (Setiady et al., 2010). Besides that, it was also reported that ouabain induces cell death in stimulated lymphocytes (Olej et al., 1998; Esteves et al., 2005; Panayiotidis et al., 2010).

In thymocytes, $\mathrm{T}$ lymphocyte precursors, ouabain is able to modulate different events such as intracellular calcium concentration increase (Echevarria-Lima et al., 2003). It was also observed that this effect is related to CD69 increased expression, a molecule associated with cell activation, induced by ouabain (Rodrigues-Mascarenhas et al., 2003). Additionally, ouabain induces in vitro intracellular free radicals accumulation and thymocytes death (Smolyaninova et al., 2013). In vivo, ouabain synergizes with hydrocortisone increasing T lymphocyte precursors death by apoptosis (Rodrigues-Mascarenhas et al., 2006), which reinforces its role as a stress-related hormone. Moreover, ouabain reduced NFAT expression and P-p38 levels, after concanavalin A stimulation (Rodrigues-Mascarenhas et al., 2008, 2009). This later data support the fact that ouabain modulates cell signaling (Xie and Askari, 2002).

Ouabain is also able to modulate in vivo B lymphocytes dynamics, decreasing mature B cells in the bone marrow, spleen and peripheral blood (de Paiva et al., 2011), although IgG and IgM levels were not affected by ouabain. On the other hand, there was an increase in B lymphocytes of mesenteric lymph node, probably by CD62L reduced and CXCR5 increased expression (da Silva et al., 2015).

Despite ouabain effects on B and T lymphocytes, natural killer (NK) cells seem to be resistant to ouabain. In fact, ouabain did not affect NK cell cytotoxic activity, in neither the absence nor presence of stimulatory agents (de Moraes et al., 1989). However, ouabain inhibits lymphokine-activated killer (LAK) cell generation induced by IL-2 (Olej et al., 1994).

Many lymphocytes functions rely on antigen presenting cells (APCs), in which dendritic cells (DC) have a highlighted role together with macrophages (Steinman, 2012). The influence of ouabain on DC was also described. Nascimento et al. (2014) demonstrated that ouabain modulates dendritic cells markers and IL-12 production during activation by TNF- $\alpha$. Additionally, ouabain affects monocyte/macrophage activation (Sowa and Przewłocki, 1997; Teixeira and Rumjanek, 2014). Indeed, ouabain reduces CD14 expression, a molecule involved in foreign antigens recognition, in human monocytes (Valente et al., 2009; Teixeira and Rumjanek, 2014). Moreover, ouabain inhibits a proinflammatory monocyte subset $\left(\mathrm{mCD} 14^{+} \mathrm{CD} 16^{+}\right)$ appearance in vitro, which may indicate that this steroid also modulates the inflammatory response.

\section{OUABAIN AS A MODULATOR OF INFLAMMATION}

Inflammation is an immunological complex response that can be triggered by pathogen- and damage-associated molecular patterns and is able to restore tissue homeostasis (Medzhitov, 2010). Acute inflammatory process is mainly characterized by vascular (e.g., vasodilation and vascular permeability) and cellular (e.g., leukocytes migration) alterations, resulting in five cardinal (clinical) signs: redness, swelling, heat, pain, and disturbance of function. Uncontrolled or unresolved 
inflammation can lead to homeostatic imbalance and chronic diseases, including cardiovascular and neurodegenerative diseases (Scrivo et al., 2011). Besides immune system role in inflammation, other systems, such as endocrine and nervous system, can also regulate this physiological response (Padro and Sanders, 2014; Procaccini et al., 2014). In fact, many hormones are known to affect inflammation, such as glucocorticoids (Cain and Cidlowski, 2017), and ghrelin, a pituitary-derived hormone (Baatar et al., 2011). In the following topics, ouabain role in the inflammatory process will be discussed.

\section{Ouabain and Peripheral Inflammation}

Acute peripheral inflammation initiates after inflammatory signals recognition (e.g., infection and tissue injury) by resident cells, such as mast cells and macrophages. This recognition promotes mediators release (e.g., vasoactive amines and prostaglandins), which stimulates rapid effects on the vasculature, including vasodilation and fluid extravasation (i.e., increased vascular permeability; Medzhitov, 2008). One of the first reports associating ouabain and inflammation revealed that this steroid suppresses vascular permeability in the sheep skin and pleural cavity induced by the irritant agent turpentine (Lancaster and Vegad, 1967). Later, our group demonstrated that ouabain given intraperitoneally decreases zymosan-induced plasma extravasation in mice peritoneal cavity (Leite et al., 2015) and reduces the mouse paw edema stimulated by several phlogistic agents (de Vasconcelos et al., 2011). However, Gonçalves-de-Albuquerque et al. (2014) showed that intratracheal administration of ouabain induces lung edema formation in mice. It is important to consider that ouabain effect on lung edema must be related to $\mathrm{Na}^{+} / \mathrm{K}^{+}$-ATPase inhibition in alveolar cells (Gonçalves-de-Albuquerque et al., 2014), while ouabain effects demonstrated by our group may be associated with cell signaling mechanisms in immune cell (e.g., P-p38 and NF- $\kappa$ B activity inhibition; Mascarenhas et al., 2014; Leite et al., 2015).

Vasodilation and vascular permeability are events tune regulated by vasoactive amines. Histamine, which plays a critical role among these vasoactive molecules, is released by perivascular mast cells together with other mediators (e.g., newly synthesized cytokines and tryptases) during inflammation (Nathan, 2002). Different ouabain effects on histamine secretion by mast cells have been described. Okazaki et al. (1976) reported that ouabain inhibits antigen-induced histamine release on guinea-pig mast cells. On the other hand, several studies revealed that ouabain increased histamine secretion induced by different agents on rat mast cells (Frossard et al., 1983; Amellal et al., 1984; Knudsen et al., 1992; Lago et al., 2001), while no ouabain effect on human mast cells (Senol et al., 2007) and basophils (Magro, 1977) were reported. Different protocols and species variation in the ouabain sensitivity of $\mathrm{Na}^{+} / \mathrm{K}^{+}$-ATPase (Abeywardena et al., 1984; Herzig and Mohr, 1984; Wang et al., 2001) could explain this discrepant ouabain effects on mast cell degranulation.

Upon initiation of acute inflammation, circulating leukocytes are able to recognize molecules (e.g., selectins, integrins, and chemokines) on activated vascular endothelium and, after rolling and adhesion steps, they cross blood vessel barrier and reach inflamed tissue (Ley et al., 2007; Vestweber, 2015; Kourtzelis et al., 2017). Neutrophils are the first cells recruited to the injured site, followed by other inflammatory cells such as monocytes (Kolaczkowska and Kubes, 2013; Wang and Arase, 2014). These polymorphonuclear leukocytes are important not only to eliminate microorganisms but they also play a key role in inflammation resolution (Mayadas et al., 2014; Sugimoto et al., 2016). Moreover, neutrophils role in chronic inflammation has been described and they are pointed as a target to emerging therapeutic strategies (Soehnlein et al., 2017). Considering this, blocking neutrophil recruitment appears to be a crucial way to avoid inflammation maintenance.

Ward and Becker (1970) initially described ouabain inhibitory effect on rabbit neutrophil migration toward bacterial chemotactic factors in vitro. In agreement with this study, our group revealed that ouabain pretreatment reduces mice neutrophil migration induced by zymosan, a component of the cell wall of yeast Saccharomyces cerevisiae, (Leite et al., 2015) and by Leishmania amazonensis (Jacob et al., 2013). These data provide clear evidence that ouabain inhibits neutrophil recruitment induced by microbial agents. This ouabain effect was also demonstrated in peritoneal inflammation induced by mitogen concanavalin A (de Vasconcelos et al., 2011). Furthermore, in airway allergic inflammation model, ouabain has an anti-migratory effect (Galvão et al., 2017). Ray and Samanta (1997) have also demonstrated that ouabain impairs in vitro human neutrophil migration, by interfering with IL-8 receptor recycling. Additionally, other studies have demonstrated that ouabain also decreases lung cancer cells migration (Liu et al., 2013), possibly by reducing the expression of molecules related to cell adhesion (e.g., integrins and ICAM) (Takada et al., 2009; Ninsontia and Chanvorachote, 2014) and cell migration (e.g., Src, Akt, and FAK) (Pongrakhananon et al., 2013; Shin et al., 2015).

However, the inhibitory effect of ouabain on cell migration seems to depend on the presence of a previous inflammatory stimulus, since ouabain itself given by inhalation (Feng et al., 2011) or intratracheally (Gonçalves-de-Albuquerque et al., 2014) causes acute lung inflammation with increased neutrophil migration. This proinflammatory effect was followed by $\mathrm{LTB}_{4}$ and $\mathrm{PGE}_{2}$ high levels, both lipid mediators associated with cell migration. Moreover, it has been demonstrated that ouabain at high concentrations induces VCAM-1 expression (an adhesion molecule) in murine endothelial cells (Bereta et al., 1995). $\mathrm{Na}^{+} / \mathrm{K}^{+}$-ATPase inhibition may be, at least partially, responsible for this ouabain effect (Lacroix-Lamandé et al., 2012; Gonçalves-de-Albuquerque et al., 2014), but $\mathrm{Na}^{+} / \mathrm{K}^{+}$-ATPase-dependent activation of signaling cascades (e.g., ERK and p38 MAPK) cannot be ruled out (Bereta et al., 1995; Feng et al., 2011). Indeed, Leu et al. (1973) demonstrated that ouabain stimulates guinea-pig alveolar and peritoneal macrophages migration independent of the sodium pump.

A different pattern of cytokines is present since the inflammation onset until resolution phase. These soluble proteins are secreted by a variety of cells (e.g., immune e non-immune cells) and allow intercellular communication, 
mediating and regulating inflammatory process. An imbalance in proinflammatory (e.g., TNF- $\alpha$ ) and anti-inflammatory (e.g., IL-10) cytokine production could entail inflammatory disorders (Tayal and Kalra, 2008; Sugimoto et al., 2016). Monocytes/macrophages are immune cells that act as a key source of cytokines because of their plasticity ability (i.e., change their pattern of cytokines and functions when exposed to different signals; Gordon and Taylor, 2005; Mantovani et al., 2014). It has been described that ouabain itself can stimulate human monocytes to secrete cytokines such as IL- $1 \alpha$, IL-1 $\beta$, IL-6, and TNF- $\alpha$ (Foey et al., 1997; Matsumori et al., 1997, 2000; Teixeira and Rumjanek, 2014). Some different results are related to IL- 6 and TNF- $\alpha$ production, which could be associated with individual variability of human donors. Indeed, critically ill patients with high levels of ouabain had higher serum concentrations of these proinflammatory cytokines and other inflammatory markers, such as C-reactive peptide and serum amyloid $\mathrm{A}$, when compared to patients with low ouabain concentrations (Berendes et al., 2003). Interestingly, ouabain enhances interleukin-10 levels in human monocytes (Teixeira and Rumjanek, 2014). Recently, Kobayashi et al. (2017) demonstrated that ouabain effect on IL-1 $\beta$ release, in both macrophages and cardiac tissue, is related to NLRP3 inflammasome activation, which in turn is mediated through $\mathrm{K}^{+}$efflux. It is noteworthy that in this study the authors used high doses of ouabain both in vitro and in vivo. This contrasts with other studies that show a reduction of a different pattern of cytokines, including IL-1 $\beta$ (Leite et al., 2015) with lower ouabain doses in presence of inflammatory stimulus (Jacob et al., 2013; Galvão et al., 2017).
Despite the well-established proinflammatory activities of some cytokines, such as TNF- $\alpha$ and IL-6, some studies have demonstrated their anti-inflammatory role (Liu et al., 1998; Zakharova and Ziegler, 2005; Masli and Turpie, 2008; Scheller et al., 2013). In this regard, use low concentrations of ouabain as cytokine immunoregulator could be useful in different clinical conditions. In fact, ouabain at low doses reverses sepsis-induced immunoparalysis by increase TNF- $\alpha$, IFN- $\gamma$, and GM-CSF levels and improve mice survival (Dan et al., 2014).

Pain is another cardinal sign of inflammation, which is also modulated by ouabain. de Vasconcelos et al. (2011) demonstrated that intraperitoneal administration of ouabain reduces nociceptive behavior in mice model of inflammatory pain (i.e., acetic acid induced writhing test). This steroid also induces supraspinal antinociceptive activity, related to opioid mechanisms, since naloxone, an opioid antagonist, inhibits its effect. In addition, other studies revealed that ouabain intracerebroventricular (i.c.v.) (Calcutt et al., 1971) and intratechal (i.t.) (Zeng et al., 1999) injections at relative high doses (micrograms) produce central antinociception and potentiate morphine and clonidine central antinociceptive effect, mainly by enhancement of cholinergic transmission at the spinal cord level (Zeng et al., 1999, 2007). In contrast, it has also been shown that low doses (nanograms) of ouabain (i.c.v.) antagonize opioid receptor agonists (Masocha et al., 2003, 2016; Gonzalez et al., 2012) and that ouabain (i.t.) itself did not cause antinociception (Horvath et al., 2003). This pain modulation by ouabain, which depends on the dose and administration route used, suggests that it can modulate events in the central nervous system such as neuroinflammation.

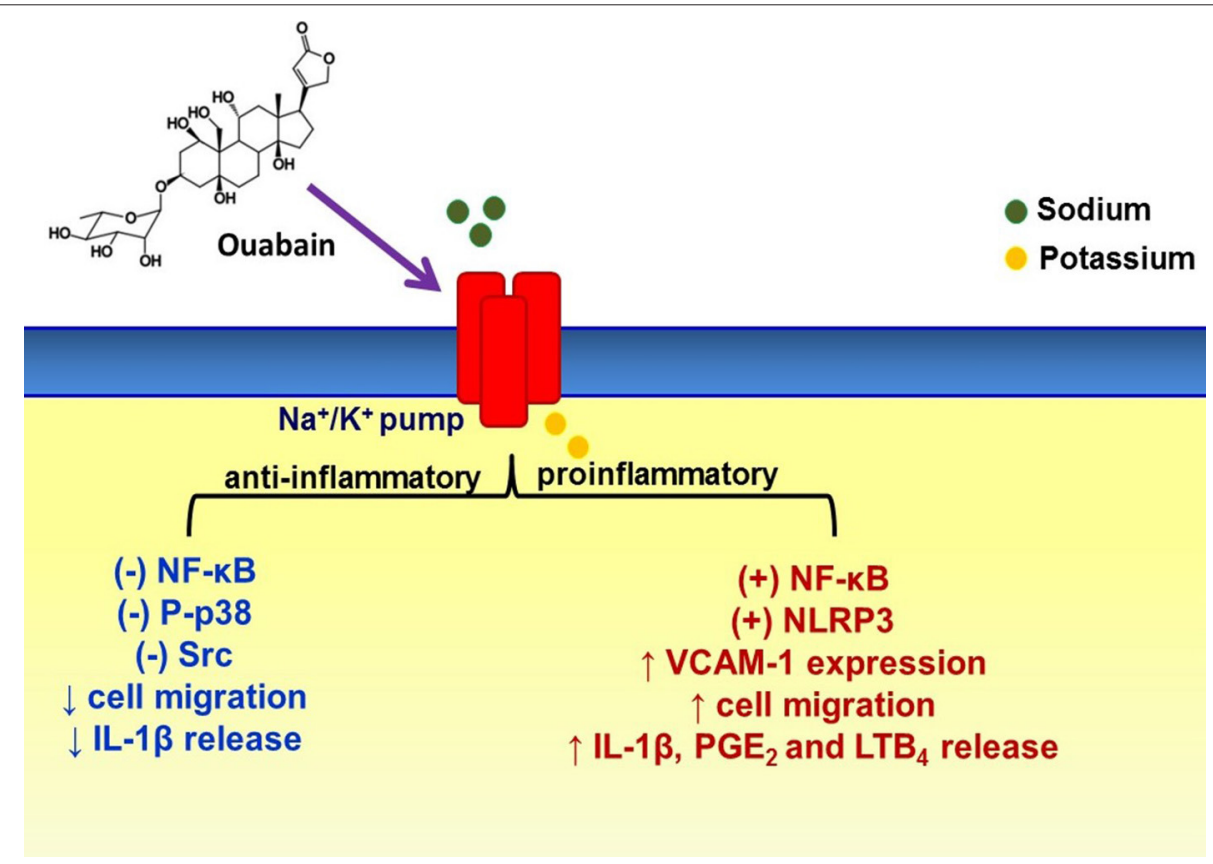

FIGURE 1 | Some cellular and molecular events modulated by ouabain on inflammatory process. Dual (pro- and anti-inflammatory) ouabain effects on the inflammation depend on some conditions such as ouabain concentration, cell type, and even functional state. This steroid hormone can modulate some cell signaling pathways due to $\mathrm{Na}^{+} / \mathrm{K}^{+}$-pump binding, which not necessarily means pump inhibition. (+) activation, $(-)$inhibition, $\uparrow$ increase, $\downarrow$ decrease. 


\section{Ouabain and Neuroinflammation}

Some studies have described ouabain role in the central nervous system (CNS). However, the effects of this steroid on neuroinflammation can be controversial. In a study with rat hippocampus, ouabain anti-inflammatory effect against neuroinflammation induced by LPS was observed. Acute intraperitoneal pre-treatment with this steroid reduced iNOS and IL-1 $\beta$ mRNA levels. In addition, ouabain also reduced

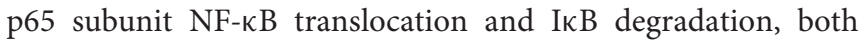
mechanisms important to inflammatory process (Kinoshita et al., 2014). However, when ouabain is administrated by intrahippocampal route in a concentration that does not inhibit $\mathrm{Na}^{+} / \mathrm{K}^{+}$-ATPase, it induces activation of NF- $\kappa \mathrm{B}$ and increases iNOS and TNF- $\alpha$ mRNA levels (Kawamoto et al., 2012). As well as in peripheral inflammation, the antiinflammatory effect of ouabain on hippocampus was only observed after an inflammatory stimulus. This could explain the different effects regarding NF- $\kappa \mathrm{B}$ activation. Additionally, another study demonstrated the ability of ouabain to restore the lipid composition of rat hippocampal membranes in neuroinflammation induced by LPS (Garcia et al., 2015).

In rat cerebellar cell culture, ouabain at high concentrations induced NF- $\kappa \mathrm{B}$ activation and consequent TNF- $\alpha$ and IL- $1 \beta$ cytokines increase through NMDA-Src-Ras pathway in absence of inflammatory stimulus (de Sá Lima et al., 2013). However, ouabain decreases IL-1 $\beta$ release in LPS-stimulated astrocytes (Forshammar et al., 2011). In spite of that, ouabain did not modulate IL-1 $\beta$ release in LPS-stimulated microglia, while increased TNF- $\alpha$ release at low concentration (Forshammar et al., 2013). Therefore, ouabain role in cytokine production at CNS level depends on cell type and concentration used. Besides that, ouabain effects on CNS could be associated with its role in

\section{REFERENCES}

Abeywardena, M. Y., McMurchie, E. J., Russell, G. R., and Charnock, J. S. (1984). Species variation in the ouabain sensitivity of cardiac $\mathrm{Na}^{+} / \mathrm{K}^{+}$-ATPase. A possible role for membrane lipids. Biochem. Pharmacol. 33, 3649-3654. doi: 10.1016/0006-2952(84)90152-7

Amellal, M., Binck, M., Frossard, N., Ilien, B., and Landry, Y. (1984). Sodium-potassium ATPase inhibition potentiates compound 48/80-induced histamine secretion from mast cells. Br. J. Pharmacol. 82, 423-430. doi: 10.1111/j.1476-5381.1984.tb10777.x

Antolovic, R., Bauer, N., Mohadjerani, M., Kost, H., Neu, H., Kirch, U., et al. (2000). Endogenous ouabain and its binding globulin: effects of physical exercise and study on the globulin's tissue distribution. Hypertens. Res. 23, S93-S98. doi: 10.1291/hypres.23.Supplement_S93

Aperia, A. (2007). New roles for an old enzyme: Na,K-ATPase emerges as an interesting drug target. J. Intern. Med. 261, 44-52. doi: 10.1111/j.1365-2796.2006.01745.x

Baatar, D., Patel, K., and Taub, D. D. (2011). The effects of ghrelin on inflammation and the immune system. Mol. Cell. Endocrinol. 340, 44-58. doi: 10.1016/j.mce.2011.04.019

Bagrov, A. Y., Shapiro, J. I., and Fedorova, O. V. (2009). Endogenous cardiotonic steroids: physiology, pharmacology, and novel therapeutic targets. Pharmacol. Rev. 61, 9-38. doi: 10.1124/pr.108.000711

Bauer, N., Müller-Ehmsen, J., Krämer, U., Hambarchian, N., Zobel, C., Schwinger, R. H., et al. (2005). Ouabain-like compound changes rapidly on physical exercise in humans and dogs: effects bipolar and depressive disorders (Goldstein et al., 2006; Tonin et al., 2014). The interaction between neuroinflammation and cardiac steroids is more substantially detailed by Orellana et al. (2016).

\section{CONCLUSIONS AND PERSPECTIVES}

In summary, compelling evidence indicates that ouabain has a pro- and anti-inflammatory effects (Figure 1), which mainly depends on its concentration and functional state of cells (i.e., absence or presence of inflammatory stimulus), corroborating other ouabain effects on the immune system. However, to the best of our knowledge, studies relating ouabain and chronic inflammation are missing. In addition, more details about ouabain mechanism of action are necessary. Lastly, ouabain effects on the inflammatory process could be better explored in order to establish possible strategies for pharmacological treatment of immune dysregulation/inflammatory diseases.

\section{AUTHOR CONTRIBUTIONS}

Conceived and designed the manuscript: SR-M and LC-S. Wrote the manuscript: LC-S, AAA, DC, ÉAL, JG, JMS-N, and JFS. Final version: SR-M.

\section{ACKNOWLEDGMENTS}

LC-S and JG are supported by Ph.D. fellowship from "Conselho Nacional de Desenvolvimento Científico e Tecnológico (CNPq)." DC, ÉAL, JMS-N, and JFS are supported by fellowship from "Coordenação de Aperfeiçoamento de Pessoal de Nível Superior" (CAPES). of beta-blockade and angiotensin-converting enzyme inhibition. Hypertension $\quad 45, \quad 1024-1028$. doi: 10.1161/01.HYP.0000165024. 47728.f7

Berendes, E., Cullen, P., Van Aken, H., Zidek, W., Erren, M., Hübschen, M., et al. (2003). Endogenous glycosides in critically ill patients. Crit. Care Med. 31, 1331-1337. doi: 10.1097/01.CCM.0000059721.57219.C3

Bereta, J., Cohen, M. C., and Bereta, M. (1995). Stimulatory effect of ouabain on VCAM-1 and iNOS expression in murine endothelial cells: involvement of NF-кB. FEBS Lett. 377, 21-25. doi: 10.1016/0014-5793(95)01301-6

Blanco, G., and Wallace, D. P. (2013). Novel role of ouabain as a cystogenic factor in autosomal dominant polycystic kidney disease. Am. J. Physiol. Renal Physiol. 305, F797-F812. doi: 10.1152/ajprenal.00248.2013

Blaustein, M. P., Chen, L., Hamlyn, J. M., Leenen, F. H., Lingrel, J. B., Wier, W. G., et al. (2016). Pivotal role of $\alpha_{2} \mathrm{Na}^{+}$pumps and their high affinity ouabain binding site in cardiovascular health and disease. J. Physiol. 594, 6079-6103. doi: $10.1113 / J P 272419$

Brodie, C., Tordai, A., Saloga, J., Domenico, J., and Gelfand, E. W. (1995). Ouabain induces inhibition of the progression phase in human T-cell proliferation. J. Cell. Physiol. 165, 246-253. doi: 10.1002/jcp.1041650205

Cain, D. W., and Cidlowski, J. A. (2017). Immune regulation by glucocorticoids. Nat. Rev. Immunol. 17, 233-247. doi: 10.1038/nri.2017.1

Calcutt, C. R., Doggett, N. S., and Spencer, P. S. (1971). Modification of the anti-nociceptive activity of morphine by centrally administered ouabain and dopamine. Psychopharmacologia 21, 111-117. doi: 10.1007/BF00572268

da Silva, J. M., das Neves Azevedo, A., dos Santos Barbosa, R. P., Vianna, T. A., Fittipaldi, J., Teixeira, M. P. et al. (2015). Dynamics of murine B lymphocytes 
is modulated by in vivo treatment with steroid ouabain. Immunobiology 221, 368-376. doi: 10.1016/j.imbio.2015.09.020

Dan, C., Jinjun, B., Zi-Chun, H., Lin, M., Wei, C., Xu, Z., et al. (2014). Modulation of TNF- $\alpha$ mRNA stability by human antigen $\mathrm{R}$ and miR181s in sepsis-induced immunoparalysis. EMBO Mol. Med. 7, 140-157. doi: 10.15252/emmm.201404797

de Moraes, V. L., Olej, B., de la Rocque, L., and Rumjanek, V. M. (1989). Lack of sensitivity to ouabain in natural killer activity. FASEB J. 3, 2425-2429.

de Paiva, L. S., Costa, K. M., Canto, F. B., Cabral, V. R., Fucs, R., Nobrega, A. et al. (2011). Modulation of mature B cells in mice following treatment with ouabain. Immunobiology 216, 1038-1043. doi: 10.1016/j.imbio.2011.03.002

de Sá Lima, L., Kawamoto, E. M., Munhoz, C. D., Kinoshita, P. F., Orellana, A. M., Curi, R., et al. (2013). Ouabain activates NFкB through an NMDA signaling pathway in cultured cerebellar cells. Neuropharmacology 73, 327-336. doi: 10.1016/j.neuropharm.2013.06.006

de Vasconcelos, D. I., Leite, J. A., Carneiro, L. T., Piuvezam, M. R., de Lima, M. R., de Morais, L. C., et al. (2011). Anti-inflammatory and antinociceptive activity of ouabain in mice. Mediat. Inflamm. 2011:912925. doi: 10.1155/2011/912925

Dornand, J., Favero, J., Bonnafous, J. C., and Mani, J. C. (1986). Mechanism whereby ouabain inhibits human $\mathrm{T}$ lymphocyte activation: effect on the interleukin 2 pathway. Immunobiology 171, 436-450.

Dvela-Levitt, M., Cohen-Ben Ami, H., Rosen, H., Ornoy, A., Hochner-Celnikier, D., Granat, M., et al. (2015). Reduction in maternal circulating ouabain impairs offspring growth and kidney development. J. Am. Soc. Nephrol. 26, 1103-1114. doi: 10.1681/ASN.2014020130

Echevarria-Lima, J., de Araújo, E. G., de Meis, L., and Rumjanek, V. M. (2003). $\mathrm{Ca}^{2+}$ mobilization induced by ouabain in thymocytes involves intracellular and extracellular $\mathrm{Ca}^{2+}$ pools. Hypertension 41, 1386-1392. doi: 10.1161/01.HYP.0000072801.90600.C2

Esteves, M. B., Marques-Santos, L. F., Affonso-Mitidieri, O. R., and Rumjanek, V. M. (2005). Ouabain exacerbates activation-induced cell death in human peripheral blood. An. Acad. Bras. Cienc. 77, 281-292. doi: 10.1590/S0001-37652005000200008

Feng, S., Chen, W., Cao, D., Bian, J., and Gong, F. Y., Cheng., W., et al. (2011). Involvement of $\mathrm{Na}(+), \mathrm{K}(+)$-ATPase and its inhibitors in HuR-mediated cytokine mRNA stabilization in lung epithelial cells.Cell Mol Life Sci. 68, 109-124. doi: 10.1007/s00018-010-0444-1

Ferrandi, M., Manunta, P., Balzan, S., Hamlyn, J. M., Bianchi, G., and Ferrari, P. (1997). Ouabain-like factor quantification in mammalian tissues and plasma: comparison of two independent assays. Hypertension 30, 886-896. doi: 10.1161/01.HYP.30.4.886

Foey, A. D., Crawford, A., and Hall, N. D. (1997). Modulation of cytokine production by human mononuclear cells following impairment of Na,K-ATPase activity. Biochim. Biophys. Acta 1355, 43-49. doi: 10.1016/S0167-4889(96)00116-4

Forshammar, J., Block, L., Lundborg, C., Biber, B., and Hansson, E. (2011). Naloxone and ouabain in ultralow concentrations restore $\mathrm{Na}^{+} / \mathrm{K}^{+}$-ATPase and cytoskeleton in lipopolysaccharide-treated astrocytes. J. Biol. Chem. 286, 31586-31597. doi: 10.1074/jbc.M111.247767

Forshammar, J., Jörneberg, P., Björklund, U., Westerlund, A., Lundborg, C., Biber, B., et al. (2013). Anti-inflammatory substances can influence some glial cell types but not others. Brain Res. 1539, 34-40. doi: 10.1016/j.brainres.2013.09.052

Frossard, N., Amellal, M., and Landry, Y. (1983). Sodiumpotassium ATPase, calcium, and immunological histamine release. Biochem. Pharmacol. 32, 3259-3262. doi: 10.1016/0006-2952(83) 90215-0

Galvão, J. G. F. M., Cavalcante-Silva, L. H. A., Carvalho, D. C. M., Ferreira, L. K. D. P., Monteiro, T. M., Alves, A. F., et al. (2017). Ouabain attenuates ovalbumin-induced airway inflammation. Inflamm. Res. 66, 1117-1130. doi: 10.1007/s00011-017-1092-9

Garcia, I. J., Kinoshita, P. F., Scavone, C., Mignaco, J. A., Barbosa, L. A., and Santos Hde, L. (2015). Ouabain modulates the lipid composition of hippocampal plasma membranes from rats with LPS-induced neuroinflammation. J. Membr. Biol. 248, 1191-1198. doi: 10.1007/s00232-015-9840-7

Goldstein, I., Levy, T., Galili, D., Ovadia, H., Yirmiya, R., Rosen, H., et al. (2006). Involvement of $\mathrm{Na}(+), \mathrm{K}(+)$-ATPase and endogenous digitalislike compounds in depressive disorders. Biol. Psychiatry 60, 491-499. doi: 10.1016/j.biopsych.2005.12.021
Gonçalves-de-Albuquerque, C. F., Burth, P., Silva, A. R., de Moraes, I. M., Oliveira, F. M., Santelli, R. E., et al. (2014). Murine lung injury caused by Leptospira interrogans glycolipoprotein, a specific Na/K-ATPase inhibitor. Respir. Res. 15:93. doi: 10.1186/s12931-014-0093-2

Gonzalez, L. G., Masocha, W., Sánchez-Fernández, C., Agil, A., Ocaña, M., Del Pozo, E., et al. (2012). Changes in morphine-induced activation of cerebral $\mathrm{Na}(+), \mathrm{K}(+)$-ATPase during morphine tolerance: biochemical and behavioral consequences. Biochem. Pharmacol. 83, 1572-1581. doi: 10.1016/j.bcp.2012.02.023

Gordon, S., and Taylor, P. R. (2005). Monocyte and macrophage heterogeneity. Nat. Rev. Immunol. 5, 953-964. doi: 10.1038/nri1733

Hamlyn, J. M., and Blaustein, M. P. (2013). Salt sensitivity, endogenous ouabain and hypertension. Curr. Opin. Nephrol. Hypertens. 22, 51-58. doi: 10.1097/MNH.0b013e32835b36ec

Hamlyn, J. M., Blaustein, M. P., Bova, S., DuCharme, D. W., Harris, D. W., Mandel, F., et al. (1991). Identification and characterization of a ouabain-like compound from human plasma. Proc. Natl. Acad. Sci. U.S.A. 88, 6259-6263. doi: 10.1073/pnas.88.14.6259

Hamlyn, J. M., Lu, Z. R., Manunta, P., Ludens, J. H., Kimura, K., Shah, J. R., et al. (1998). Observations on the nature, biosynthesis, secretion and significance of endogenous ouabain. Clin. Exp. Hypertens. 20, 523-533. doi: 10.3109/10641969809053230

Hauck, C., and Frishman, W. H. (2012). Systemic hypertension: the roles of salt, vascular $\mathrm{Na} / \mathrm{K}$ ATPase and the endogenous glycosides, ouabain and marinobufagenin. Cardiol. Rev. 20, 130-138. doi: 10.1097/CRD.0b013e31823c835c

Herzig, S., and Mohr, K. (1984). Action of ouabain on rat heart: comparison with its effect on guinea-pig heart. Br. J. Pharmacol. 82, 135-142. doi: 10.1111/j.1476-5381.1984.tb16450.x

Horvath, G., Agil, A., Joo, G., Dobos, I., Benedek, G., and Baeyens, J. M. (2003). Evaluation of endomorphin-1 on the activity of $\mathrm{Na}(+), \mathrm{K}(+)$ ATPase using in vitro and in vivo studies. Eur. J. Pharmacol. 458, 291-297. doi: 10.1016/S0014-2999(02)02813-3

Jacob, P. L., Leite, J. A., Alves, A. K., Rodrigues, Y. K., Amorim, F. M., Néris, P. L., et al. (2013). Immunomodulatory activity of ouabain in Leishmania leishmania amazonensis-infected Swiss mice. Parasitol. Res. 112, 1313-1321. doi: 10.1007/s00436-012-3146-9

Jensen, P., Winger, L., Rasmussen, H., and Nowell, P. (1977). The mitogenic effect of A23187 in human peripheral lymphocytes. Biochim. Biophys. Acta 496, 374-383. doi: 10.1016/0304-4165(77)90320-8

Kawamoto, E. M., Lima, L. S., Munhoz, C. D., Yshii, L. M., Kinoshita, P. F., Amara, F. G., et al. (2012). Influence of N-methyl-D-aspartate receptors on ouabain activation of nuclear factor-kappaB in the rat hippocampus. J. Neurosci. Res. 90, 213-228. doi: 10.1002/jnr.22745

Kinoshita, P. F., Yshii, L. M., Vasconcelos, A. R., Orellana, A. M., Lima Lde, S., Davel, A. P., et al. (2014). Signaling function of Na, K-ATPase induced by ouabain against LPS as an inflammation model in hippocampus. $J$. Neuroinflamm. 11:218. doi: 10.1186/s12974-014-0218-z

Knudsen, T., Bertelsen, H., and Johansen, T. (1992). Ouabain enhancement of compound 48/80 induced histamine secretion from rat peritoneal mast cells: dependence on extracellular sodium. Pharmacol. Toxicol. 70, 412-418. doi: 10.1111/j.1600-0773.1992.tb00499.x

Kobayashi, M., Usui-Kawanishi, F., Karasawa, T., Kimura, H., Watanabe, S., Mise, N., et al. (2017). The cardiac glycoside ouabain activates NLRP3 inflammasomes and promotes cardiac inflammation and dysfunction. PLoS ONE 12:e0176676. doi: 10.1371/journal.pone.0176676

Kolaczkowska, E., and Kubes, P. (2013). Neutrophil recruitment and function in health and inflammation. Nat. Rev. Immunol. 13, 159-175. doi: 10.1038/nri3399

Kourtzelis, I., Mitroulis, I., von Renesse, J., Hajishengallis, G., and Chavakis, T. (2017). From leukocyte recruitment to resolution of inflammation: the cardinal role of integrins. J. Leukoc. Biol. 102, 677-683. doi: 10.1189/jlb.3MR01 17-024R

Lacroix-Lamandé, S., d'Andon, M. F., Michel, E., Ratet, G., Philpott, D. J., Girardin, S. E., et al. (2012). Downregulation of the Na/K-ATPase pump by leptospiral glycolipoprotein activates the NLRP3 inflammasome. J. Immunol. 188, 2805-2814. doi: 10.4049/jimmunol.1101987

Lago, J., Alfonso, A., Vieytes, M. R., and Botana, L. M. (2001). Ouabaininduced enhancement of rat mast cells response. Modulation by 
protein phosphorylation and intracellular pH. Cell Signal. 13, 515-524. doi: 10.1016/S0898-6568(01)00169-3

Lancaster, M. C., and Vegad, J. L. (1967). Suppression of the early inflammatory response in the sheep by strophanthin G. Nature 213, 840-884. doi: $10.1038 / 213840 \mathrm{~b} 0$

Laredo, J., Hamilton, B. P., and Hamlyn, J. M. (1994). Ouabain is secreted by bovine adrenocortical cells. Endocrinology 135, 794-797. doi: 10.1210/endo.135.2.8033829

Laredo, J., Hamilton, B. P., and Hamlyn, J. M. (1995). Secretion of endogenous ouabain from bovine adrenocortical cells: role of the zonaglomerulosa and zonafasciculata. Biochem. Biophys. Res. Commun. 212, 487-493. doi: 10.1006/bbrc.1995.1996

Laredo, J., Shah, J. R., Lu, Z. R., Hamilton, B. P., and Hamlyn, J. M. (1997). Angiotensin II stimulates secretion of endogenous ouabain from bovine adrenocortical cells via angiotensin type 2 receptors. Hypertension 29, 401-407. doi: 10.1161/01.HYP.29.1.401

Leite, J. A., Alves, A. K., Galvão, J. G., Teixeira, M. P., Cavalcante-Silva, L. H., Scavone, C. et al.,(2015). Ouabain modulates zymosan-induced peritonitis in mice. Med. Inflamm. 2015:265798. doi: 10.1155/2015/265798

Leu, R. W., Eddleston, A. W., Good, R. A., and Hadden, J., W (1973). Paradoxical effects of ouabain on the migration of peritoneal and alveolar macrophages. Exp. Cell Res. 76, 458-461. doi: 10.1016/0014-4827(73)90403-5

Lewis, L. K., Yandle, T. G., Hilton, P. J., Jensen, B. P., Begg, E. J., and Nicholls, M. G. (2014). Endogenous ouabain is not ouabain. Hypertension 64, 680-683. doi: 10.1161/HYPERTENSIONAHA.114.03919

Ley, K., Laudanna, C., Cybulsky, M. I., and Nourshargh, S. (2007). Getting to the site of inflammation: the leukocyte adhesion cascade updated. Nat. Rev. Immunol. 7, 678-689. doi: 10.1038/nri2156

Lingrel, J. B. (2010). The physiological significance of the cardiotonic steroid/ouabain-binding site of the Na,K-ATPase. Annu. Rev. Physiol. 72, 395-412. doi: 10.1146/annurev-physiol-021909-135725

Liu, J., Marino, M. W., Wong, G., Grail, D., Dunn, A., Bettadapura, J., et al. (1998). TNF is a potent anti-inflammatory cytokine in autoimmune-mediated demyelination. Nat. Med. 4, 78-83. doi: 10.1038/nm0198-078

Liu, N., Li, Y., Su, S., Wang, N., Wang, H., and Li, J. (2013). Inhibition of cell migration by ouabain in the A549 human lung cancer cell line. Oncol. Lett. 6, 475-479. doi: 10.3892/ol.2013.1406

Magro, A. M. (1977). Blocking of histamine release from human basophils in vitro by the ATPase inhibitor, ethacrynic acid. Clin. Exp. Immunol. 29, 436-441.

Mantovani, A., Vecchi, A., and Allavena, P. (2014). Pharmacological modulation of monocytes and macrophages. Curr. Opin. Pharmacol. 17, 38-44. doi: 10.1016/j.coph.2014.07.004

Manunta, P., Ferrandi, M., Bianchi, G., and Hamlyn, J. M. (2009). Endogenous ouabain in cardiovascular function and disease. J. Hypertens. 27, 9-18. doi: 10.1097/HJH.0b013e32831cf2c6

Manunta, P., Messaggio, E., Casamassima, N., Gatti, G., Carpini, S. D., Zagato, L., et al. (2010). Endogenous ouabain in renal $\mathrm{Na}^{+}$handling and related diseases. Biochim. Biophys. Acta 1802, 1214-1218. doi: 10.1016/j.bbadis.2010.03.001

Mascarenhas, S., Leite, J., Galvão, G., and Alves, A. (2014). Effect of ouabain on NFKB and p-38 activation in macrophages: a new biotechnological application. BMC Proc. 8 (Suppl. 4):P260. doi: 10.1186/1753-6561-8-S4-P260

Masli, S., and Turpie, B. (2008). Anti-inflammatory effects of tumour necrosis factor (TNF)-alpha are mediated via TNF-R2 (p75) in tolerogenic transforming growth factor-beta-treated antigen-presenting cells. Immunology 127, 62-72. doi: 10.1111/j.1365-2567.2008.02933.x

Masocha, W., González, L. G., and Agil, A. (2016). Distinguishing subgroups among $\mu$-opioid receptor agonists using $\mathrm{Na}(+), \mathrm{K}(+)$-ATPase as an effector mechanism. Eur. J. Pharmacol. 774, 43-49. doi: 10.1016/j.ejphar.2016.01.010

Masocha, W., Horvath, G., Agil, A., Ocana, M., Del Pozo, E., Szikszay, M., et al. (2003). Role of $\mathrm{Na}(+), \mathrm{K}(+)$-ATPase in morphine-induced antinociception. J. Pharmacol. Exp. Ther. 306, 1122-1128. doi: 10.1124/jpet.103.052977

Masugi, F., Ogihara, T., Hasegawa, T., Sakaguchi, K., and Kumahara, Y. (1988). Normalization of high plasma level of ouabain-like immunoreactivity in primary aldosteronism after removal of adenoma. J. Hum. Hypertens. 2, 17-20.

Matsumori, A., Ono, K., Nishio, R., Igata, H., Shioi, T., Matsui, S., et al. (1997). Modulation of cytokine production and protection against lethal endotoxemia by the cardiac glycoside ouabain. Circulation 96, 1501-1506. doi: 10.1161/01.CIR.96.5.1501
Matsumori, A., Ono, K., Nishio, R., Nose, Y., and Sasayama, S. (2000). Amlodipine inhibits the production of cytokines induced by ouabain. Cytokine 12, 294-297. doi: $10.1006 /$ cyto. 1999.0555

Mayadas, T. N., Cullere, X., and Lowell, C. A. (2014). The multifaceted functions of neutrophils. Annu. Rev. Pathol. 9, 181-218. doi: 10.1146/annurev-pathol-020712-164023

Medzhitov, R. (2008). Origin and physiological roles of inflammation. Nature 454, 428-435. doi: 10.1038/nature07201

Medzhitov, R. (2010). Inflammation 2010: new adventures of an old flame. Cell 140, 771-776. doi: 10.1016/j.cell.2010.03.006

Nascimento, C. R., Valente, R. C., Echevarria-Lima, J., Fontes, C. F., de Araujo-Martins, L., Araujo, E. G., et al. (2014). The influence of ouabain on human dendritic cells maturation. Med. Inflamm. 2014, 4949-4956. doi: $10.1155 / 2014 / 494956$

Nathan, C. (2002). Points of control in inflammation. Nature 420, 846-852. doi: $10.1038 /$ nature 01320

Nesher, M., Dvela, M., Igbokwe, V. U., Rosen, H., and Lichtstein, D. (2009). Physiological roles of endogenous ouabain in normal rats. Am. J. Physiol. Heart Circ. Physiol. 297, H2026-H2034. doi: 10.1152/ajpheart.0073 4.2009

Ninsontia, C., and Chanvorachote, P. (2014). Ouabain mediates integrin switch in human lung cancer cells. Anticancer Res. 34, 5495-5502.

Okazaki, T., Ilea, V. S., Okazaki, A., Wicher, K., Reisman, R. E., and Arbesman, C. E. (1976). Inhibition of antigen-induced histamine release by ouabain. J. Allergy Clin. Immunol. 57, 454-462. doi: 10.1016/0091-6749(76)90061-0

Olej, B., de La Rocque, L., Castilho, F. P., Mediano, I. F., Campos, M. M., and Rumjanek, V. M. (1994). Effect of ouabain on lymphokine-activated killer cells. Int. J. Immunopharmacol. 16, 769-774. doi: 10.1016/0192-0561(94)9 0097-3

Olej, B., dos Santos, N. F., Leal, L., and Rumjanek, V. M. (1998). Ouabain induces apoptosis on PHA-activated lymphocytes. Biosci. Rep. 18, 1-7. doi: 10.1023/A:1022259832207

Orellana, A. M., Kinoshita, P. F., Leite, J. A., Kawamoto, E. M., and Scavone, C. (2016). Cardiotonic steroids as modulators of neuroinflammation. Front. Endocrinol. 7:10. doi: 10.3389/fendo.2016.00010

Padro, C. J., and Sanders, V. M. (2014). Neuroendocrine regulation of inflammation. Semin. Immunol. 26, 357-368. doi: 10.1016/j.smim.2014.01.003

Panayiotidis, M. I., Franco, R., Bortner, C. D., and Cidlowski, J. A. (2010). Ouabain-induced perturbations in intracellular ionic homeostasis regulate death receptor-mediated apoptosis. Apoptosis 15, 834-849. doi: 10.1007/s10495-010-0494-8

Parkin, J., and Cohen, B. (2001). An overview of the immune system. Lancet 357, 1777-1789. doi: 10.1016/S0140-6736(00)04904-7

Pires, V., Harab, R. C., Olej, B., and Rumjanek, V. M. (1997). Ouabain effects on activated lymphocytes: augmentation of CD25 expression on TPA-stimulated cells and of CD69 on PHA- and TPA-stimulated cells. Int. J. Immunopharmacol. 19, 143-147. doi: 10.1016/S0192-0561(96)00070-7

Pongrakhananon, V., Chunhacha, P., and Chanvorachote, P. (2013). Ouabain suppresses the migratory behavior of lung cancer cells. PLOS ONE 8:e68623. doi: 10.1371/journal.pone.0068623

Procaccini, C., Pucino, V., De Rosa, V., Marone, G., and Matarese, G. (2014). Neuro-endocrine networks controlling immune system in health and disease. Front. Immunol. 5:143. doi: 10.3389/fimmu.2014.00143

Quastel, M. R., and Kaplan, J. G. (1968). Inhibition by ouabain of human lymphocyte transformation induced by phytohaemagglutinin in vitro. Nature 219, 198-200. doi: 10.1038/219198a0

Ray, E., and Samanta, A. K. (1997). Receptor-mediated endocytosis of IL-8: a fluorescent microscopic evidence and implication of the process in ligandinduced biological response in human neutrophils. Cytokine 9, 587-596. doi: 10.1006/cyto.1997.0206

Redondo, J. M., López Rivas, A., and Fresno, M. (1986). Activation of the $\mathrm{Na}^{+} / \mathrm{K}^{+}$-ATPase by interleukin-2. FEBS Lett. 206, 199-202. doi: 10.1016/0014-5793(86)80980-2

Rodrigues-Mascarenhas, S., Bloise, F. F., Moscat, J., and Rumjanek, V. M. (2008). Ouabain inhibits p38 activation in thymocytes. Cell. Biol. 32, 1323-1328. doi: 10.1016/j.cellbi.2008.07.012

Rodrigues-Mascarenhas, S., Da Silva de Oliveira, A., Amoedo, N. D., AffonsoMitidieri, O. R., Rumjanek, F. D., and Rumjanek, V. M. (2009). Modulation 
of the immune system by ouabain. Ann. N. Y. Acad. Sci. 1153, 153-163. doi: 10.1111/j.1749-6632.2008.03969.x

Rodrigues-Mascarenhas, S., dos Santos, N. F., and Rumjanek, V. M. (2006). Synergistic effect between ouabain and glucocorticoids for the induction of thymic atrophy. Biosci. Rep. 26, 159-169. doi: 10.1007/s10540-006-9012-1

Rodrigues-Mascarenhas, S., Echevarria-Lima, J., Fernandes dos Santos, N., and Rumjanek, V. M. (2003). CD69 expression induced by thapsigargin, phorbol ester and ouabain on thymocytes is dependent on external $\mathrm{Ca}^{2+}$ entry. Life Sci. 73, 1037-1051. doi: 10.1016/S0024-3205(03)00377-1

Rossi, G., Manunta, P., Hamlyn, J. M., Pavan, E., De Toni, R., Semplicini, A., et al. (1995). Immunoreactive endogenous ouabain in primary aldosteronism and essential hypertension: relationship with plasma renin, aldosterone and blood pressure levels. J. Hypertens. 13, 1181-1191. doi: 10.1097/00004872-199510000-00013

Saunders, R., and Scheiner-Bobis, G. (2004). Ouabain stimulates endothelin release and expression in human endothelial cells without inhibiting the sodium pump. Eur. J. Biochem. 271, 1054-1062. doi: 10.1111/j.1432-1033.2004. 04012.x

Scheller, J., Chalaris, A., Schmidt-Arras, D., and Rose-John, S. (2013).The pro- and anti-inflammatory properties of the cytokine interleukin-6. Biochim. Biophys. Acta 1813, 878-888. doi: 10.1016/j.bbamcr.2011.01.034

Schneider, R., Wray, V., Nimtz, M., Lehmann, W. D., Kirch, U., Antolovic, R., et al. (1998). Bovine adrenals contain, in addition to ouabain, a second inhibitor of the sodium pump. J. Biol. Chem. 273, 784-792. doi: 10.1074/jbc.273.2.784

Schoner, W., and Scheiner-Bobis, G. (2005). Endogenous cardiac glycosides: hormones using the sodium pump as signal transducer. Semin. Nephrol. 25, 343-351. doi: 10.1016/j.semnephrol.2005.03.010

Schoner, W. (2002). Endogenous cardiac glycosides, a new class of steroid hormones. Eur. J. Biochem. 269, 2440-2448. doi: $10.1046 /$ j.1432-1033.2002.02911.x

Schoner, W., and Scheiner-Bobis, G. (2007). Endogenous and exogenous cardiac glycosides and their mechanisms of action. Am. J. Cardiovasc. Drugs 7, 173-189. doi: 10.2165/00129784-200707030-00004

Scrivo, R., Vasile, M., Bartosiewicz, I., and Valesini, G. (2011). Inflammation as "common soil" of the multifactorial diseases. Autoimmun. Rev. 10, 369-374. doi: 10.1016/j.autrev.2010.12.006

Senol, M., Ozerol, I. H., Patel, A. V., and Skoner, D. P. (2007). The effect of Na+$\mathrm{K}+$ ATPase inhibition by ouabain on histamine release from human cutaneous mast cells. Mol. Cell. Biochem. 294, 25-29. doi: 10.1007/s11010-006-9180-0

Setiady, Y. Y., Coccia, J. A., and Park, P. U. (2010). In vivo depletion of $\mathrm{CD}^{+}{ }^{\mathrm{FOXP}_{3}}{ }^{+}$Treg cells by the PC61 anti-CD25 monoclonal antibody is mediated by FcgammaRIII ${ }^{+}$phagocytes. Eur. J. Immunol. 40, 780-786. doi: $10.1002 /$ eji. 200939613

Shin, H. K., Ryu, B. J., Choi, S.-W., Kim, S. H., and Lee, K. (2015). Inactivation of Src-to-ezrin pathway: a possible mechanism in the ouabainmediated inhibition of A549 cell migration. Biomed. Res. Int. 2015:537136. doi: $10.1155 / 2015 / 537136$

Silva, J. M., Das Neves Azevedo, A., Corrêa Aleixo, R., Mendes Clemente, A., Ribeiro Cabral, V., and Paiva, L. S. (2015). Ouabain improves the response to melanoma (B16) in mice by modulating B and T lymphocytes. Front. Immunol. Conference Abstract: IMMUNOCOLOMBIA2015 - 11th Congress of the Latin American Association of Immunology - 10o. Congreso de la Asociación Colombiana de Alergia, Asma e Inmunología.

Smolyaninova, L. V., Dergalev, A. A., Kulebyakin, K. Y., Carpenter, D. O., and Boldyrev, A. A. (2013). Carnosine prevents necrotic and apoptotic death of rat thymocytes via ouabain sensitive Na/K-ATPase. Cell Biochem. Funct. 31, 30-35. doi: $10.1002 / \mathrm{cbf} .2856$

Soehnlein, O., Steffens, S., Hidalgo, A., and Weber, C. (2017). Neutrophils as protagonists and targets in chronic inflammation. Nat. Rev. Immunol. 17, 248-261. doi: 10.1038/nri.2017.10

Sowa, G., and Przewłocki, R. (1997). Ouabain enhances the lipopolysaccharideinduced nitric oxide production by rat peritoneal macrophages. Immunopharmacol 36, 95-100. doi: 10.1016/S0162-3109(96)00159-2

Steinman, R. M (2012). Decisions about dendritic cells: past, present, and future. Annu. Rev. Immunol. 30, 1-22. doi: 10.1146/annurev-immunol-100311-102839

Stella, P., Manunta, P., Mallamaci, F., Melandri, M., Spotti, D., Tripepi, G. et al. (2008). Endogenous ouabain and cardiomyopathy in dialysis patients. J. Intern Med. 263, 274-280. doi: 10.1111/j.1365-2796.2007.01883.x
Sugimoto, M. A., Sousa, L. P., Pinho, V., Perretti, M., and Teixeira, M. M. (2016). Resolution of inflammation: what controls its onset? Front. Immunol. 7:160. doi: 10.3389/fimmu.2016.00160

Szamel, M., Leufgen, H., Kurrle, R., and Resch, K. (1995). Differential signal transduction pathways regulating interleukin-2 synthesis and interleukin-2 receptor expression in stimulated human lymphocytes. Biochim. Biophys. Acta 1235, 33-42. doi: 10.1016/0005-2736(94)00297-3

Takada, Y., Matsuo, K., Ogura, H., Bai, L., Toki, A., Wang, L., et al.,(2009). Odoroside $\mathrm{A}$ and ouabain inhibit $\mathrm{Na}+/ \mathrm{K}+$-ATPase and prevent NFkappaB inducible protein expression by blocking $\mathrm{Na}+$-dependent amino acid transport. Biochem. Pharmacol. 78, 1157-1166. doi: 10.1016/j.jpain.2007.07.006

Tayal,V., and Kalra, B. S. (2008). Cytokines and anti-cytokines as therapeutics-an update. Eur. J. Pharmacol. 579, 1-12. doi: 10.1016/j.ejphar.2007.10.049

Teixeira, M. P., and Rumjanek, V. M. (2014). Ouabain affects the expression of activation markers, cytokine production, and endocytosis of human monocytes. Med. Inflamm. 2014, 7603-7668. doi: 10.1155/2014/ 760368

Tonin, P. T., Valvassori, S. S., Lopes-Borges, J., Mariot, E., Varela, R. B., Teixeira, A. L., et al. (2014). Effects of ouabain on cytokine/chemokine levels in an animal model of mania. J. Neuroimmunol. 276, 236-239. doi: 10.1016/j.jneuroim.2014.09.007

Tymiak, A. A., Norman, J. A., Bolgar, M., DiDonato, G. C., Lee, H., Parker, W. L., et al. (1993). Physicochemical characterization of a ouabain isomer isolated from bovine hypothalamus. Proc Natl Acad Sci.U.S.A. 90, 8189-8193. doi: $10.1073 /$ pnas.90.17.8189

Valente, R. C., Nascimento, C. R., Araujo, E. G., and Rumjanek, V., M (2009). mCD14 expression in human monocytes is downregulated by ouabain via transactivation of epithelial growth factor receptor and activation of p38 mitogen activated protein kinase. Neuroimmunomodulation 16, 228-236. doi: $10.1159 / 000212383$

Vestweber, D. (2015). How leukocytes cross the vascular endothelium. Nat. Rev. Immunol. 15, 692-704. doi: 10.1038/nri3908

Wang, J., and Arase, H. (2014). Regulation of immune responses by neutrophils. Ann. N. Y. Acad. Sci. 1319, 66-81. doi: 10.1111/nyas.12445

Wang, J., Velotta, J. B., McDonough, A. A., and Farley, R. A. (2001). All human $\mathrm{Na}(+)-\mathrm{K}(+)$-ATPase alpha-subunit isoforms have a similar affinity for cardiac glycosides. Am. J. Physiol. Cell Physiol. 281, C1336-C1343.

Ward, P. A., and Becker, E. L. (1970). Potassium reversible inhibition of leukotaxis by ouabain. Life Sci. 9, 355-360. doi: 10.1016/0024-3205(70)90 $180-3$

Xie, Z., and Askari, A. (2002). $\mathrm{Na}^{+} / \mathrm{K}^{+}$-ATPase as a signal transducer. Eur. J. Biochem. 269, 2434-2439. doi: 10.1046/j.1432-1033.2002.02910.x

Xie, Z., and Cai, T. (2003). $\mathrm{Na}^{+}-\mathrm{K}^{+}$-ATPase-mediated signal transduction: from protein interaction to cellular function. Mol. Interv. 3, 157-168. doi: $10.1124 / \mathrm{mi} .3 .3 .157$

Zakharova, M., and Ziegler, H. K. (2005). Paradoxical anti-inflammatory actions of TNF-alpha: inhibition of IL-12 and IL-23 via TNF receptor 1 in macrophages and dendritic cells. J. Immunol. 175, 5024-5033. doi: 10.4049 /jimmunol.175.8.5024

Zeng, W., Chen, X., and Dohi, S. (2007). Antinociceptive synergistic interaction between clonidine and ouabain on thermal nociceptive tests in the rat. J. Pain 8, 983-988. doi: 10.1016/j.bcp.2009.06.027

Zeng, W., Dohi, S., Shimonaka, H., and Asano, T. (1999). Spinal antinociceptive action of $\mathrm{Na}^{+}-\mathrm{K}^{+}$pump inhibitor ouabain and its interaction with morphine and lidocaine in rats. Anesthesiology 90, 500-508. doi: 10.1097/00000542-199902000-00026

Conflict of Interest Statement: The authors declare that the research was conducted in the absence of any commercial or financial relationships that could be construed as a potential conflict of interest.

Copyright @ 2017 Cavalcante-Silva, Lima, Carvalho, Sales-Neto, Alves, Galvão, Silva and Rodrigues-Mascarenhas. This is an open-access article distributed under the terms of the Creative Commons Attribution License (CC BY). The use, distribution or reproduction in other forums is permitted, provided the original author(s) or licensor are credited and that the original publication in this journal is cited, in accordance with accepted academic practice. No use, distribution or reproduction is permitted which does not comply with these terms. 